\title{
Is real depreciation and expansionary fiscal policy effective? The case of Serbia
}

\section{Yu Hsing * $(\mathbb{D}$, Yun-Chen Morgan **}

* College of Business, Southeastern Louisiana University,

Hammond, Louisiana, 70402, USA

Ph.D., Joseph H. Miller Endowed Professor in Business, Department of Management \& Business Administration

** College of Business, Southeastern Louisiana University,

Hammond, Louisiana, 70402, USA

Ph.D., Instructor, Department of Management \& Business Administration

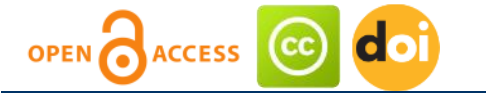

Article history:

Received: September 27, 2017

1st Revision: September

30, 2017

Accepted: October 23, 2017

JEL classification:

E62

F31

\section{DOI:}

10.14254/jems.2017.2-2.3
Abstract: Applying the IS-MP-IA model to study the impacts of exchange rate movements, expansionary fiscal policy and other relevant variables in Serbia, we find that real appreciation of the dinar, a higher government deficit-to-GDP ratio, a lower real lending rate in the euro area, a lower lagged real oil price, a higher Germany's real GDP and a lower expected inflation rate would promote economic growth.

Keywords: currency depreciation, budget deficits, government debt, interest rates, IS-MP-IA model.

\section{Introduction}

There are strengths and weaknesses in Serbia's economy. The 2.8\% growth rate of real GDP in 2016 ranked the best since 2009. The inflation rate declined from a recent high of $12.1 \%$ in 2012 to a low of $1.6 \%$ in 2016 . The average lending rate declined rapidly from a recent high of $19.47 \%$ in 2013.Q1 to 8.45\% in 2016.Q4, providing incentives for households and businesses to borrow and spend. However, the central government debt as a percent of GDP rose rapidly from $28.3 \%$ in 2008 to $73.0 \%$ in 2016 partly due to expansionary fiscal policy to rescue the economy caused by the global financial crisis. Imports were greater than exports, leading to a trade deficit of $7.57 \%$ of the GDP. The $15.3 \%$ unemployment rate in 2016 is much higher than the unemployment rates in the U.S. and the EU, suggesting that there was slack in the labor market.

The Serbian dinar depreciated 99.59\% from 55.76 dinars per U.S. dollar in 2008 to 111.29 dinars per U.S. dollar in 2016. Depreciation of the dinar tends to increase exports, reduce imports

Corresponding author: $Y u$ Hsing

E-mail: yhsing@selu.edu

This open access article is distributed under a Creative Commons Attribution (CC-BY) 4.0 license. 
and create more job opportunities. On the other hand, a weaker dinar tends to increase the cost of imports and domestic inflation, cause capital outflows, and reduce investments by foreign investors. Whether dinar depreciation would help or hurt aggregate output needs to be addressed empirically.

There have been several articles studying the effect of currency depreciation in Serbia and related countries. Stučka (2003) indicates that a J curve exists in Croatia, that deterioration of the trade balance is short lived, and that it would take 2.5 years for the trade balance to improve. The study for Croatia may be relevant for Serbia as these two countries had a similar economic history under the former Yugoslavia.

Based on a sample of 11 East European countries during 1990.M1 - 2005.M6, BahmaniOskooee and Kutan (2009) study the impact of currency depreciation on the balance of trade and reveal that the J-curve effect is found to exist in Bulgaria, Croatia and Russia. It suggests that after currency depreciation, their trade balance would deteriorate in the short run and improve in the long run.

Using a sample during 2002.M1 - 2007.M9, Petrović and Gligorić (2010) show that depreciation of the Serbian dinar resulted in a J curve in the short run and an improvement in the trade balance in the long run.

Kurtovic, Halili, and Maxhuni (2017) find that in the import demand function, a J-curve effect in the short term was found for Serbia's bilateral trade with Croatia, Germany and Italy. But such a J-curve effect was not found in Serbia's export demand function.

The Serbian government also applies fiscal policy to increase aggregate demand and output. In order to rescue the economy due to the global financial crisis, the government budget deficit-toGDP ratio rose from $1.7 \%$ in 2008 to $6.3 \%$ in 2014 . Whether expansionary fiscal policy would raise real GDP is unclear mainly because the crowding-out effect may cancel out some or all of the increase in real GDP. Several studies have examined fiscal policy in Serbia. Đukić and Redžepagić (2010) advocate that Serbia needs to pursue fiscal responsibility to limit government spending and debt. They propose that the Serbian government creates a Fiscal Council consisting of experts for successful implementation in order for Serbia to meet the convergence criteria and to become an EU member in the future.

Jovancai-Stakić and Stokanović (2015) examine whether Serbia may achieve the Maastricht convergence criteria of less than $60 \%$ of the debt-to-GDP ratio and less than $3 \%$ of the deficit-toGDP ratio. They predict that Serbia will have a deficit-to-GDP ratio of 3.8\% and a government debtto-GDP ratio of $78.7 \%$ by 2017 unless it pursues a restrictive fiscal policy including a tax reform.

Andrić, Arsić and Nojković (2016) estimate the fiscal reaction function (FRF) for Serbia and find that Serbia's government debt-to-GDP ratio has a unit root with an upward trend, that primary fiscal balance does not respond to government debt sufficiently to revert the upward trend of government debt, and that the path of Serbia's debt-to-GDP ratio is not sustainable during the sample period.

Đurović-Todorović, Đorđević and Vuković (2017) find that Serbia's public debt is a crisis, that Serbia's public debt was less than the benchmark debt up to 2011 and was greater than the benchmark debt since 2012, and that public spending violates the benchmark debt criterion.

This paper attempts to assess whether currency depreciation or expansionary fiscal policy would be conducive to economic growth in Serbia. This paper differs from previous studies because it applies the IS-MP-IA model (Romer, 2000; 2006) and employs an advanced econometric methodology to estimate regression parameters.

\section{Theoretical Model}

Extending Romer (2000; 2006), we can express the IS, monetary policy and inflation adjustment functions as:

$$
\begin{aligned}
& Y=W\left(Y, R, G, T, \varepsilon, E, Y^{*}\right) \\
& R=X\left(\pi, Y, \varepsilon, R^{*}\right) \\
& \pi=Z\left(\pi^{e}, Y, E, \varepsilon\right)
\end{aligned}
$$

where

$Y=$ real GDP in Serbia,

$R=$ the real interest rate,

$G=$ government spending,

$T$ = government tax revenue,

$\varepsilon=$ the real effective exchange rate,

$E=$ the real energy price, 


$$
\begin{aligned}
& Y^{*}=\text { world real GDP or income, } \\
& \pi=\text { the inflation rate, } \\
& R^{*}=\text { world real interest rate, and } \\
& \pi^{e}=\text { the expected inflation rate. }
\end{aligned}
$$

Solving for the three endogenous variables $Y, R$ and $\pi$ simultaneously, we can find the equilibrium real GDP as:

$$
\begin{gathered}
\bar{Y}=f\left(\varepsilon, G-T, R^{*}, E, Y^{*}, \pi^{e}\right) \\
? \quad ? \quad-+-
\end{gathered}
$$

The sign beneath each of the exogenous variables shows the partial derivative of $\bar{Y}$ with respect to a change in each of the exogenous variables.

An analysis of the data shows that real GDP exhibits seasonal variations. Hence, three seasonable dummy variables are included in the estimated regression:

$$
\bar{Y}=h\left(\varepsilon, G-T, R^{*}, E, Y^{*}, \pi^{e}, S 1, S 2, S 3\right)
$$

where $S 2, S 3$ and $S 4$ represent the second quarter, the third quarter and the fourth quarter, respectively.

\section{Empirical Results}

The data were collected from the National Bank of Serbia and the International Financial Statistics published by the International Monetary Fund. Real GDP in Serbia is measured in million dinars. The budget deficit as a percent of GDP is used to represent fiscal policy. The real lending rate in the euro area is selected to represent the world real interest rate as monetary policy conducted by the European Central Bank is expected to affect monetary policy of the National Bank of Serbia. The real effective exchange rate is a trade-weighted index, and an increase means real appreciation of the dinar. The real oil price is selected to represent the real energy price and is measured as the dinar per barrel of crude oil adjusted by the consumer price index. The lagged real oil price is used as there may be a time lag for its impact on aggregate economy to be realized. Real GDP in Germany is measured in billion euros. The expected inflation rate is estimated as an average inflation rate in the past four quarters. The sample ranges from 2005.Q1 to 2016.Q4 and has a total of 48 observations. The data for the budget deficit are not available before 2005.Q1.

Figure 1 shows the scatter diagram between real GDP and the real effective exchange rate. It seems that an increase in the real effective exchange rate or real appreciation of the dinar raised real GDP during the sample period. Figure 2 describes the relationship between real GDP and the government deficit as a percent of GDP. It appears that a higher deficit-to-GDP ratio increased real GDP during the sample period. Figure 3 presents the scatter diagram between Serbia's real GDP and Germany's real GDP. It looks like that a higher real GDP in Germany would help increase real GDP in Serbia. These relationships need to be tested by multiple regression analysis in order to separate the effects of other related variables from the effect of each of the above exogenous variables.

The ADF test on the regression residual is performed. The value of the test statistic is 4.8904 , and the critical value is -4.1658 at the $1 \%$ level. Hence, these variables are cointegrated and have a long-term stable relationship.

Table 1 reports the estimated regression and related statistics. Approximately $91.45 \%$ of the change in real GDP can be explained by the nine right-hand side variables. The coefficients of all the exogenous variables are significant at the 1\% level. Real GDP in Serbia has a positive relationship with the real effective exchange rate, the government deficit as a percent of GDP, Germany's real GDP and three seasonal dummy variables and a negative relationship with the real lending rate in the euro area, the lagged real oil price and the expected inflation rate. In percent terms, the real effective exchange rate and Germany's real GDP have the largest impacts. A 1\% real appreciation of the dinar would cause real GDP to rise by $0.3527 \%$, and a $1 \%$ increase in Germany's real GDP would raise Serbia's real GDP by $0.3309 \%$. 
Figure 1: Scatter Diagram between Serbia's Real GDP (REALGDP) and the Real Effective Exchange Rate (REER)

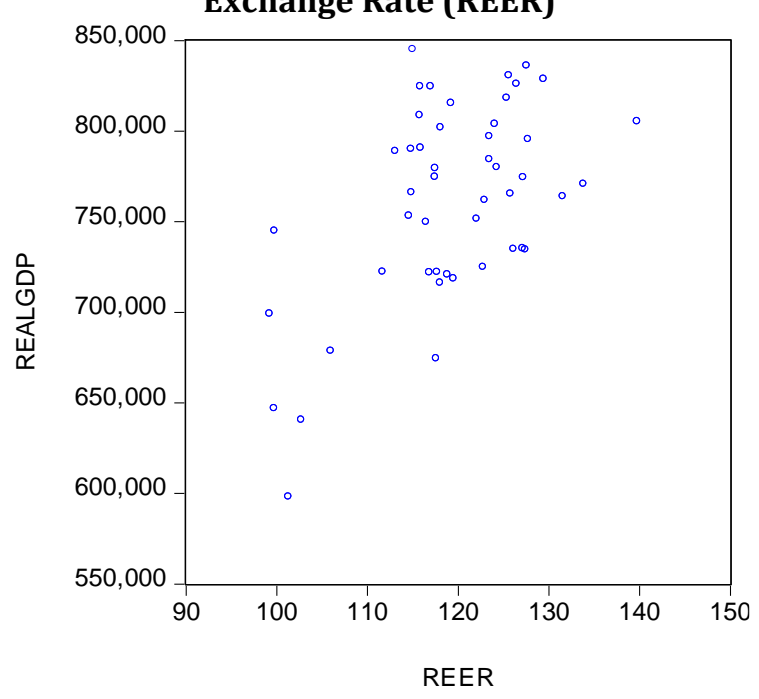

Figure 2: Scatter Diagram between Serbia's Real GDP (REALGDP) and the Deficit-to-GDP

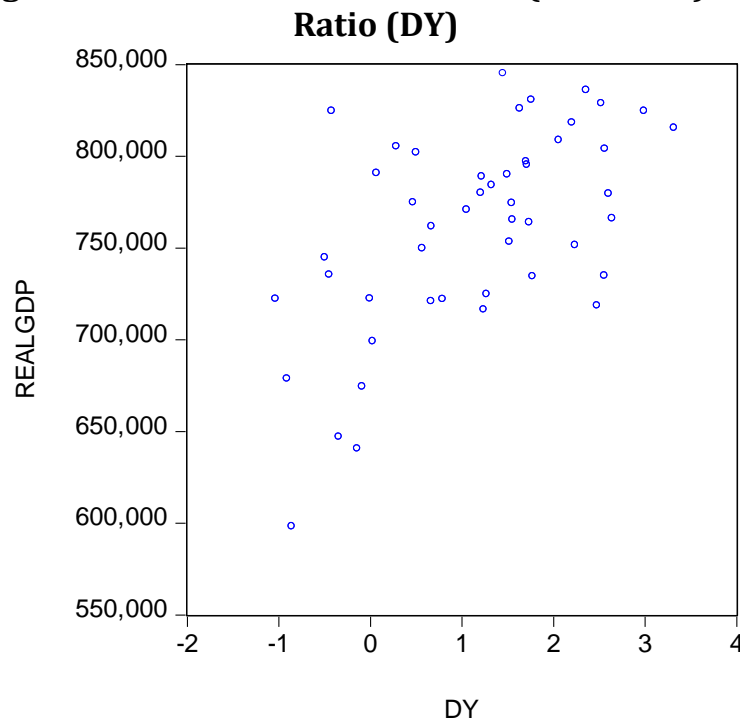

Figure 3. Scatter Diagram between Serbia's Real GDP (REALGDP) and Germany's Real GDP

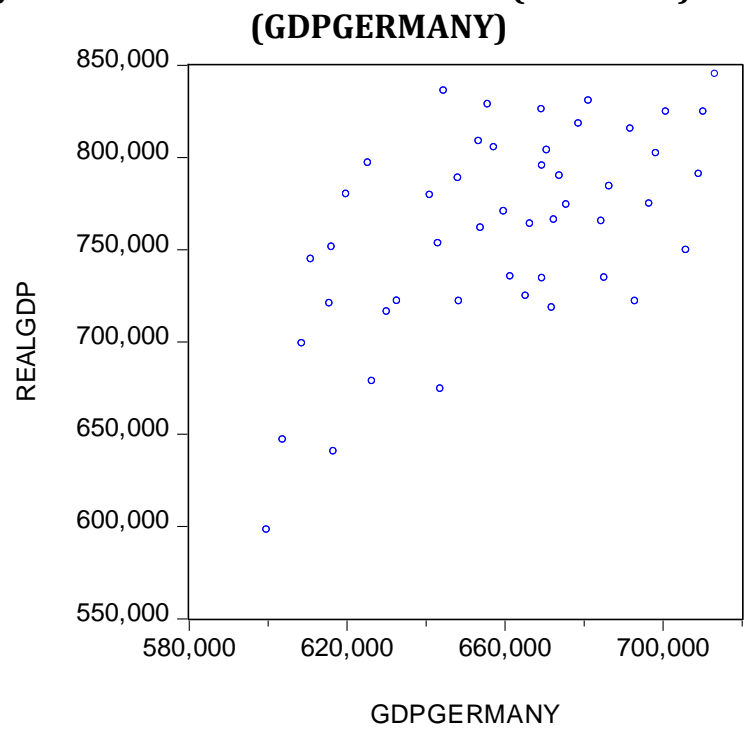


Table 1: Estimated Regression of Log (Real GDP) in Serbia

\begin{tabular}{lccc}
\multicolumn{1}{c}{ Variable } & Coefficient & z-Statistic & Probability \\
\hline C & 7.701027 & 637.0611 & 0.0000 \\
Log(real effective exchange rate) & 0.352685 & 127.1198 & 0.0000 \\
Government deficit-to-GDP ratio & 0.007195 & 2.644413 & 0.0082 \\
Euro area real lending rate & -0.003582 & -2.562591 & 0.0104 \\
Log(lagged real oil price) & -0.036405 & -89.97358 & 0.0000 \\
Log(Germany's real GDP) & 0.330913 & 256.2451 & 0.0000 \\
Expected inflation rate & -0.004891 & -4.304041 & 0.0000 \\
Second quarter & 0.044653 & 6.827350 & 0.0000 \\
Third quarter & 0.083196 & 10.78143 & 0.0000 \\
Fourth quarter & 0.114241 & 14.55364 & 0.0000 \\
& & & \\
R-squared & 0.914528 & & \\
Adjusted R-squared & 0.894285 & & \\
Akaike information criterion & -4.732775 & & \\
Schwarz criterion & -4.225991 & & \\
Sample period & & & \\
Number of observations & $2005 . Q 1-2016.04$ & & \\
Methodology & 48 & & \\
MAPE & GARCH & & \\
\hline
\end{tabular}

Notes: MAPE stands for the mean absolute percent error.

Several comments can be made. The positive significant coefficient of the real effective exchange rate suggests that real appreciation of the dinar from 99 in $2005 . Q 3$ to 140 in 2008.Q3 tends to help raise real GDP and that recent real depreciation of the dinar from 127 in $2013 . Q 1$ to 115 in 2016.Q4 tends to hurt real GDP. The positive significant coefficient of the government deficit as a percent of GDP indicates that expansionary fiscal policy is effective and the crowding-out effect does not cancel out all the positive impact of a higher government deficit-to-GDP ratio on real GDP. The negative significant coefficient of the real oil price implies that a higher real oil price tends to increase the inflation rate and the real interest rate and reduce real GDP.

Several other versions were considered. When the real exchange rate measured as the units of the dinar per U.S. dollar times relative prices in the U.S. and Serbia replaces the real effective exchange rate, the estimated coefficient of -0.1500 is significant at the $1 \%$ level, and the value of Rsquared is 0.8877 . However, the negative coefficients of the real lending rate in the euro area and the expected inflation rate become insignificant at the $10 \%$ level. The higher value of R-squared reported in Table 1 suggests that the real effective exchange rate based on international trade with major trading partners tends to be a better measurement of the real exchange rate. If the expected inflation rate is represented by the simple lagged inflation rate, its estimated coefficient of -0.0063 is significant at the $1 \%$ level. Other results are similar. Attempts were made to use government debt as a percent of GDP as a proxy for fiscal policy without success due to lack of adequate data.

\section{Conclusions}

This paper has examined the impacts of exchange rate movements, government deficit spending and other related variables on aggregate output in Serbia. The IS-MP-IA model is applied. The GARCH model is employed in empirical work. Real appreciation of the dinar, expansionary fiscal policy, a lower real lending rate in the euro area, a lower real oil price, more Germany's output or a lower expected inflation rate would raise real GDP in Serbia.

There are several policy implications. It appears that recent real depreciation of the dinar may hurt real GDP as potential benefits of real depreciation such as more exports may be outweighed by potential negative impacts such as higher imports costs, higher domestic inflation, increase in capital outflows, and decrease in foreign investments. Although more deficit spending as a percent of GDP would raise real GDP, there may be a threshold level beyond which a further increase in the government deficit-to-GDP ratio may be unsustainable. Hence, fiscal prudence would be needed. The authorities may need to pay more attention to external factors such as world real income, world real interest rates and the real cost of imported oil. A lower world real income, a higher world real interest rate or a higher real crude oil price would shift aggregate demand to the left and the inflation adjustment curve to the left, causing Serbia's real GDP to decline. 


\section{Appendix A. Supplementary material}

Supplementary data associated with this article can be found, in the online version, at https://dx.doi.org/10.14254/jems.2017.2-2.3

\section{Funding}

The authors received no direct funding for this research.

\section{Citation information}

Hsing, Y., \& Morgan, Y.-C. (2017). Is real depreciation and expansionary fiscal policy effective? The case of Serbia. Economics, Management and Sustainability, 2(2), 24-30. doi:10.14254/jems.2017.2-2.3.

\section{References}

Andrić, V., Arsic, M., \& Mladenovic, Z. (2016). The dynamics of public debt in Serbia-A nonlinear analysis (No. 144713). ZBW-German National Library of Economics.

Andrić, V., Arsić, M., \& Nojković, A. (2016). Public debt sustainability in Serbia before and during the global financial crisis. Economic Annals, 61(210), 47-77.

Arsić, M. (2015). Highlights 4. What is necessary for the sustainable growth of the Serbian economy? Of Economic Trends and Policies in Serbia, 71.

Bahmani-Oskooee, M., \& Kutan, A. M. (2009). The J-curve in the emerging economies of Eastern Europe. Applied Economics, 41(20), 2523-2532.

Bishev, G., \& Boskov, T. (2015). Exchange rate and export-led growth in SEE6: Economic convergence machine-What happened? What next?.

Bungin, S., Reljić, M., \& Ivković, B. (2015). Estimation of transmission mechanism of monetary policy in Serbia. Industrija, 43(3), 143-158.

Cassou, J. D., Erce-Domínguez, A., \& Zamora, J. J. V. (2008). Recent episodes of sovereign debt restructurings. A case-study approach. Documentos ocasionales-Banco de España, (4), 9-84.

Dragana, P., Đurović-Todorović, J., \& Prole, L. (2014). The dynamycs of the volume and structure of interest on the public debt of the Republic of Serbia. Ekonomika, 60(4).

Đukić, M., \& Redžepagić, S. (2010). Fiscal responsibility and public debt. Economic Growth and Development of Serbia New Model, 329.

Đurović-Todorović, J., Đorđević, M., \& Vuković, M. (2017). Fiscal stress analysis in the Republic of Serbia. Economic Themes, 55(1), 55-69.

Fabris, J. (2015). Inflation targeting in Serbia. Journal of Central Banking Theory and Practice, 4(2), 59-74.

Grubišić, Z., \& Kamenković, S. (2015). An analysis of the effects of the economic policy in Serbia by the Mundell-Fleming Model. Economic Themes, 53(1), 51-62.

Ignjatijevic, I. M. S., \& Đorðevic, D. (2016). Analysis of investment factors which are influencing the growth of the Republic of Serbia. Ekonomika Poljoprivrede, 63(4), 1205.

Janković, N. (2015). A twin deficit: The issue of the Serbian economy. Ekonomski horizonti, 17(2), 109-124.

Jovancai-Stakić, A., \& Stokanović, J. (2015). The possibility of reaching the fulfillment of Maastricht convergence criteria in Serbia. Megatrend revija, 12(2), 111-122.

Krstevska, A. (2015). Monetary policy objectives during the crisis: An overview of selected Southeast European Countries. Journal of Central Banking Theory and Practice, 4(1), 35-46.

Kurtovic, S., Halili, B., \& Maxhuni, N. (2017). Bilateral trade elasticity of Serbia: Is there a J-curve effect? PSL Quarterly Review, 70(281).

Miletić, S. (2015). Modeling exchange rate volatility in CEEC countries: Impact of global financial and European sovereign debt crisis. Megatrend revija, 12(1), 105-122. 
Petrović, P., \& Gligorić, M. (2010). Exchange rate and trade balance: J-curve effect. Panoeconomicus, 57(1), 23-41.

Petrovic, P., \& Mladenovic, Z. (2015). Exchange rate pass-through and the frequency of price adjustment across different inflation regimes. Panoeconomicus, 62(4), 409.

Romer, D. (2000) Keynesian macroeconomics without the LM curve. Journal of Economic Perspectives, 14, 149-169.

Romer, D. (2006) Advanced Macroeconomics. New York, NY: McGraw-Hill.

Stojanović, D., \& Stojanović, D. (2017). Monetary policy transmission mechanisms in Serbia: evidence from the fully-fledged inflation targeting regime. Post-Communist Economies, 29(1), 117-137.

Stučka, T. (2003). The impact of exchange rate changes on the trade balance in Croatia. Croatian National Bank Working Paper Series, No. W-11, October 2003.

Tabaković, J. (2017). Central bank policy after the crisis: Example of Serbia. Ekonomika preduzeća, 65(1-2), 83-102.

Tesic, A., Ilic, D., \& Đelic, A. T. (2014). Consequences of fiscal deficit and public debt in financing the public sector. Ekonomika Poljoprivrede, 61(1), 177.

Yazici, M., \& Islam, M. Q. (2014). Exchange rate and bilateral trade balance of Turkey with EU (15) Countries. Journal of Business Economics and Finance, 3(3), 341-356.

Zdravković, A., Bradić-Martinović, A., \& Stefanović, S. (2012). Sustainability of Serbian public debt in regard to economic crisis. Ekonomski signali, 7(1), 1-18.

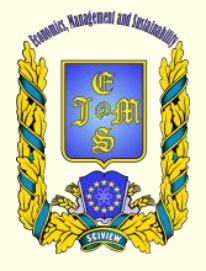

๑) 2016-2017, Economics, Management and Sustainability. All rights reserved.

This open access article is distributed under a Creative Commons Attribution (CC-BY) 4.0 license.

You are free to:

Share - copy and redistribute the material in any medium or format Adapt - remix, transform, and build upon the material for any

purpose, even commercially.

The licensor cannot revoke these freedoms as long as you follow the license terms.

Under the following terms:

Attribution - You must give appropriate credit, provide a link to the license, and indicate if changes were made.

You may do so in any reasonable manner, but not in any way that suggests the licensor endorses you or your use.

No additional restrictions

You may not apply legal terms or technological measures that legally restrict others from doing anything the license permits.

Economics, Management and Sustainability (ISSN: 2520-6303) is published by Scientific Publishing House "CSR", Poland, EU and Scientific Publishing House "SciView", Poland

Publishing with JEMS ensures:

- Immediate, universal access to your article on publication

- High visibility and discoverability via the JEMS website

- Rapid publication

- Guaranteed legacy preservation of your article

- Discounts and waivers for authors in developing regions

Submit your manuscript to a JEMS at https://jems.sciview.net or submit.jems@sciview.net

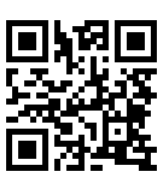

